\title{
ФИЛОСОФИЯ
}

DOI: https://doi.org/10.15688/lp.jvolsu.2020.3.1

УДК $130.2,140.8$

ББК 87.52

\section{PHILOSOPHICAL FOUNDATIONS OF RENÉ GIRARD'S FUNDAMENTAL ANTROPOLOGY}

\author{
Elena N. Shulga \\ Institute of Philosophy, Russian Academy of Sciences, Moscow, Russian Federation
}

\begin{abstract}
René Girard (1923-2015) - French philosopher, professor of Stanford University, the member of Académie Française, the author of numerous works, some of which have recently become accessible to the Russian audience. His most popular books: "Resurrection from the Underground", "Violence and the Sacred", "Things Hidden since the Foundation of the World", "Job, the Victim of His People", "I See Satan Fall Like Lightning", "The Scapegoat". However, René Girard's conceptual heritage has not been properly appreciated by philosophers due to the diversity of creative aspirations of the thinker. Most often, he is called a professional philologist, religious scholar, cultural scientist, and his work as an innovator in the field of social and humanitarian sciences is associated with the creation of fundamental anthropology and the theory of culture based on it. Studying the works of René Girard is an exciting activity, supposing the immersion in the literary texts and biblical stories analyzed by him. These texts serve the author as a basis for solving the questions of vital importance for human existence and being. The search for answers to vital questions has always concerned both philosophers and theologians. Above all those are the questions related to the grasping of spiritual truths. Not always Girard formulated their meaning directly but through the introducing concepts that reveal the deeper aspects of socially directed human actions, providing these actions with a new categorical meaning. Thus, in the book "The Scapegoat", which will be analyzed in the given paper, the philosopher shows that the human ability to perceive own misery as the punishment for the specific misbehavior or sins is just the superficial point of view and it witnesses of the introvert character of the man/woman. But any personal catastrophe is also a sacrifice - precisely such point of view according to the biblical story of Job not only reconciles the man with life circumstances but raises him over them. Girard shows that the search for external causes that explain human misfortunes or catastrophes on a larger scale runs through the entire history of mankind is reflected in literature, historical and cultural monuments from Sophocles to Jesus. This article is devoted to the interpretation of the main conceptual ideas of Girard from the position of philosophical hermeneutics in order to clarify the philosophical foundations of fundamental anthropology.
\end{abstract}

Key words: philosophy, hermeneutics, text, interpretation, victim, persecution.

УДК $130.2,140.8$

ББК 87.52

\section{ФИЛОСОФСКИЕ ОСНОВАНИЯ ФУНДАМЕНТАЛЬНОЙ АНТРОПОЛОГИИ РЕНЕ ЖИРАРА}

\author{
Елена Николаевна Шульга \\ Институт философии РАН, г. Москва, Российская Федерация
}

Аннотация. Рене Жирар (1923-2015) - французский философ, профессор Стэнфордского университета, член Французской академии, автор многочисленных трудов, некоторые из которых стали в последние годы доступными российскому читателю. Его наиболее известные книги: «Путь древних, по которому шли 
люди беззаконные», «Насилие и священное», «Козел отпущения», «Критика из подполья», «Я вижу Сатану, падающего как молния», «Вещи, сокрытые от создания мира». Однако концептуальное наследие Рене Жирара все еще не получило должной оценки со стороны философов в силу многоплановости творческих устремлений самого мыслителя. Чаще всего его называют профессиональным филологом, религиоведом, культурологом, а его деятельность как новатора в области социально-гуманитарных наук связывают с созданием фундаментальной антропологии и основанной на ней теории культуры. Изучение трудов Рене Жирара - это захватывающее занятие, предполагающее погружение в анализируемые им литературные тексты и библейские сюжеты. Эти тексты служат автору основанием для решения самых животрепещущих вопросов человеческого бытия и существования. Поиск ответов на жизненно важные вопросы всегда волновали как философов, так и теологов. Прежде всего, это вопросы, связанные с постижением духовных истин. Их смысл Жирар не всегда выражает прямо, но посредством введения понятий, раскрывающих глубинные стороны социально направленных действий человека, придавая этим действиям новый категориальный смысл. Так, в книге «Козел отпущения», о которой пойдет речь в данной статье, философ показывает, что способность человека воспринимать собственные несчастья как наказание за какие-либо конкретные проступки или грехи - это только поверхностный взгляд, и он свидетельствует об обращенности человека на самого себя. Но любая личная катастрофа - это еще и жертвенность; именно такой взгляд, как об этом повествует библейская история Иова, не только примиряет человека с житейскими обстоятельствами, но поднимает его над этими обстоятельствами. Жирар показывает, что поиск внешних причин, объясняющих человеческие невзгоды или катастрофы более широкого масштаба, проходит сквозь всю историю человечества, находит отражение в литературе, в памятниках истории и культуры от Софокла до Христа. Интерпретации основных концептуальных идей Жирара с позиции философской герменевтики с целью выяснения философских оснований фундаментальной антропологии как раз и посвящена данная статья.

Ключевые слова: философия, герменевтика, текст, интерпретация, жертва, гонение.

\section{Введение}

Для развития философской мысли $\mathrm{XX}-$ XXI вв. характерно разнообразие философских течений и появление множества философских концепций, которые не конкурируют между собой и, как правило, не занимаются взаимной критикой, но представляют собой самостоятельные направления исследований внутри самой философии. Эти философские направления формируют собственные предметные области, исходя из принципа преемственности знания в изучении традиционных философских вопросов, обосновывая и решая проблемы способами, которые призваны полностью преобразовать философию в первую очередь благодаря введению новых подходов или посредством аргументации, направленной на обоснование основополагающих концептуальных положений. Перечислю только некоторые такие направления: философия жизни, экзистенциализм, прагматизм, структурализм, философская герменевтика, неопозитивизм, неотомизм, феноменология, философская антропология, виталистический иррационализм и новая реалистическая метафизика, философия науки. Предметная сфера каждой из названных направлений философских исследо- ваний определяется тем кругом проблем, которые рассматриваются как центральные, наиболее важные, актуальные для развития данного философского направления. В свою очередь, часто именно вокруг тематики, совокупности рассматриваемых проблем и используемых подходов и методов организуется круг философов, объединенных общими философскими интересами. О вкладе этих философов - создателей новых парадигм - уместно говорить как в связи с мировоззренческой позицией, которую они отстаивают, так и в связи со спецификой преимущественного стиля мышления, например, аналитического стиля мышления, который стал характерным для многих философов ХХ века.

В связи с этим последним обстоятельством стоит, по-видимому, обратить внимание на объективные причины, в силу которых можно ясно наблюдать те изменения, которые происходили в философии под влиянием открытий в науке, прежде всего, в естествознании. Возникновение теории относительности и квантовой теории не только перевернуло традиционную, классическую научную картину мира, но, вместе с тем, оказало двоякое влияние на философию в целом, на ее проблематику и методологию. С одной стороны, современная 
философия стремится приблизиться к стандартам научности, например, в строгости и непротиворечивости выдвигаемых суждений и обосновываемых концептуальных положений. С другой стороны, философия постоянно смягчает эпистемический образец научного обоснования, широко используя тропы и художественные приемы (аналогии, аллегории, метафоры) в изложении материала исследований.

Что касается философского осмысления изменений, сопровождающих развитие социально-гуманитарных дисциплин, то нельзя не обратить внимание на конкретизацию роли философии в становлении и развитии гуманитарного знания, учитывая то, как эту роль определяют сами философы. Так, рассуждая о характере взаимосвязи философии и наук гуманитарной направленности, академик B.С. Степин отмечает: «Философия участвует в обосновании открытий социально-гуманитарных наук и вместе с тем получает в свое распоряжение эмпирический материал, опираясь на который решает задачи выработки новых категориальных смыслов, адресуемых будущему» [Степин 2015, 209]. Степин характеризует «обоснование» как важный способ утверждения статуса научного знания, распространяемого, в частности, на культурологию и философию культуры. «Как и во всяком теоретическом поиске, - рассуждает философ, здесь создаются особые понятия и теоретические конструкты, которые могут выходить за рамки обыденного здравого смысла и не состыковываться с ним... Поэтому необходима состыковка новых, необычных с позиций здравого смысла образов культуры, с привычными устоявшимися представлениями. Эту задачу выполняет философское обоснование, что является одним из условий включения новых идей в поток культурных трансляций» [Степин 2015, 209]. Предлагаемая исследовательская установка, связанная с выходом за рамки обыденного смысла, не противоречит герменевтическому подходу как методу, нацеленному на преодоление очевидности поверхностных смыслов ради понимания истинного содержания и глубинного, часто скрытого от поверхностного суждения, смысла произведения. Отталкиваясь в своем исследовании творчества Рене Жирара от этой методо- логической установки, попытаемся воспроизвести, реконструировать философскую позицию философа, его взгляд на историю и культуру, обращаясь к совершенно определенной идее - утверждению культурно-исторической преемственности в понимании природы человека, как она представлена в книге «Козел отпущения» [Жирар 2010].

Следует подчеркнуть, что различные аспекты последовательно развиваемой Рене Жираром фундаментальной антропологии представлены в его многочисленных трудах, некоторые из которых стали доступными российскому читателю. Его наиболее известные книги: «Путь древних, по которому шли люди беззаконные» [Girard 1985], «Насилие и священное» [Жирар 2000], «Козел отпущения» [Жирар 2010], «Критика из подполья» [Жирар 2012], «Я вижу Сатану, падающего как молния» [Жирар 2015], «Вещи, сокрытые от создания мира» [Жирар 2016].

Концептуальное наследие Рене Жирара все еще не получило должной оценки со стороны философов в силу многоплановости творческих устремлений самого мыслителя. Чаще всего его называют профессиональным филологом, религиоведом, культурологом, а его деятельность как новатора в области социально-гуманитарных наук связывают с созданием фундаментальной антропологии и основанной на ней теории культуры [Goodhart et al. (eds.) 2009]. Исследователи творчества Жирара сопоставляют его концепции с учениями Фрейда, Маркса, Руссо, Ницше, Гегеля и других [Palaver 2013]. Высказанные им идеи побудили многих современных авторов по-новому взглянуть на соотношение насилия и религии, на библейского Бога и смерть Христа [Swartley 2000].

Для Рене Жирара человеческая жизнь вращается вокруг миметического желания, которое так всеобъемлюще, что он определяет его как «онтологическую болезнь» [Reineke 2014]. Жираровская теория козла отпущения - маргинальной личности, угрожающей социальному порядку - предлагает критический взгляд на религиоведение и общество [Smith, Wallace 1994]. По мнению других авторов, это взгляд на корни насилия и на условие человечности вообще [Ryba, Redekop 2013]. Любое обсуждение теории жертвопри- 
ношения, вплоть до современной феминистской критики, не обходится без упоминания работ Жирара в контексте религиозной и философской мысли, литературных произведений и фильмов [Meszaros, Zachhuber 2013]. Часто ключевые элементы антропологии Рене Жирара эксплицируются в терминах литературной теории Жака Деррида, создавая тем самым новую интерпретативную стратегию как спасение метода деконструкции от привычной банальной бесплодности [McKenna 1992]. Наконец, применение теории козла отпущения к библейским текстам привело к формулировке радикальной революционной парадигмы библейской теории [Schwager 2000].

Следует подчеркнуть, что интерпретация идей Рене Жирара связана не только с пониманием его трудов (а понимание как раз и есть важнейший аспект герменевтического анализа текста), но и с пониманием описываемых автором человеческих действий, скрытый смысл которых приобретает культурноисторические и общечеловеческие черты.

\section{Герменевтические аспекты фундаментальной антропологии Рене Жирара}

Предметной областью современной философской герменевтики является проблема понимания и интерпретации. Многовековой опыт практики истолкования текстов с самым разным содержанием придал герменевтике статус дисциплины с ярко выраженной методологической направленностью, которая состоит в выработке и систематизации общих и специальных методов интерпретации, которые используются для лучшего понимания изучаемого текста (философского, научного, религиозного, литературно-художественного). Истолкованию подвергаются не только различные тексты, но и объекты научного исследования, исторические факты, наиболее значимые события, социально-политические процессы, а также литературные произведения отдельных исторических эпох, типы культур, образы художественно-изобразительного искусства и т. д. Все многообразие сфер применения герменевтического анализа дает право утверждать, что герменевтический подход может применяться всюду, где человек (ис- следователь) сталкивается с необходимостью понять, объяснить и интерпретировать все то, на что направлено его познание.

С того момента, как В. Дильтей разделил знание на естественнонаучное, связанное с объяснением, и гуманитарное знание, обращенное к пониманию, перед исследователями встала задача обоснования исходных оснований гуманитарного знания. Поиск объективных условий понимания и интерпретации социокультурных процессов и восприятие (понимание) событий, превосходящих их объяснение на уровне здравого обыденного смысла, объединяет герменевтику с другими областями гуманитарного познания. «Предметной областью герменевтики становится человеческая действительность, которая, согласно Дильтею, подлежит не только истолкованию (или интерпретации), но и пониманию» [Шульга 2008, 14].

Исторически сложилось так, что герменевтический анализ обычно применяется к текстам (отдельным фрагментам), смысл которых не всегда может быть понят однозначно и нуждается в истолковании. Поэтому герменевтику можно характеризовать как дисциплину, имеющую непосредственное отношение к смыслу - она ищет подлинный смысл, который намеревался передать автор текста. Более широкий взгляд на герменевтику связан с выявлением смысла отдельного произведения, являющегося существенно значимым (порой даже решающим) для воспроизведения концептуального смысла целого философского направления и его целей. В данной статье речь пойдет о некоторых фундаментальных идеях антропологической концепции и их философском значении.

Изложение свой концепции в книге «Козел отпущения» Рене Жирар начинает с пересказа содержания различных литературных произведений прошлого, в которых мотив жертвы представлен наиболее отчетливо и где прослеживается мысль о роли гонителей в объяснении несчастий, свалившихся на людей. Так, французский поэт Гийом де Машо, который жил в XIV в., в сочинении под названием «Суд короля Наваррского» прямо указывает на то, что каменный дождь, убивший людей, сожженные ударами молний города, отравленные источники питьевой воды, наконец, эпи- 
демия черной чумы, унесшая множество жизней - все эти несчастья вызваны ни чем иным, как «зловредностью евреев и их сообщников из числа христиан. ...Но небесная справедливость пресекла эти злодеяния, открыв их зачинщиков населению, которое всех их истребило» [Жирар 2010, 11]. Как можно заметить, подобная оценка ответственности небольшой группы людей за то, что они не совершали и не могли бы совершить, и последующая вслед за обвинениями казнь не имеет никакого отношения к происходившим в это время природным явлениям или к факту многочисленных смертей вследствие быстрого распространения эпидемии. Однако у поэта все это безапелляционно и немотивированно сопряжено с проявлением «небесной справедливости», которая указывает на зачинщиков всех несчастий, карает их и снимает тем самым с других людей ответственность за их истребление.

Для современного исследователя такое объяснение кажется неправдоподобным и даже нелепым. Однако для Гийома де Машо, свидетеля этих событий, несомненно, важно связать истребление «виновных» с проявлением небесной справедливости, в силу которой коллективная ответственность за казнь переносится непосредственно на избранных жертв. Поиск жертв не случаен. Дело в том, что иногда совместить объяснение причины внезапных природных явлений и катастроф, болезней и многочисленных смертей, постигших мирных граждан, с их последствиями и ущербом для невинного населения, довольно трудно, в особенности если все это вместе превосходит восприятие их человеком с позиции здравого смысла. Поэтому люди порой вынуждены искать причины невзгод в злокозненной деятельности «чужаков» и мнимых врагов. Отсюда - поиск жертв, и это, как правило, люди в чем-то иные, например, люди чужой культуры, другого уклада жизни или в чем-то превосходящие своих соотечественников или соседей. Превосходство одного человека над другими, или в нашем примере одной малой группы людей над всеми остальными, часто становится «черной меткой», причиной выбора тех или иных персон в качестве жертвы. Именно их и рассматривают как непосредственных виновников развернувшейся трагедии. Наказание «виновных» в глазах людей неискушенных ассоциируется с проявлением некой высшей справедливости, небесной кары за злокозненность и якобы порочность самой их природы. У Гийома де Машо это «Гнусная Иудея, злая, неверная, которая ненавидит добро и любит всякое зло. Много у ней и золота, и серебра, и столько денег посулила она христианам, что колодцы, реки и источники, которые были чистыми и здоровыми, оказались во многих местах отравлены. От этого многие лишились жизни... Вот так случилась эта беда» [Жирар 2010, 13].

Как истинный ученый, Жирар рассуждает о самой возможности рассматривать литературные произведения как источники сведений о событиях, имевших место в действительности. Так, поэтический текст де Машо, на первый взгляд, не имеет исторического значения, поскольку сами события и указанные в тексте причины несчастий и катастроф кажутся недостоверными. Однако Жирар настаивает на том, что описываемые поэтом события вполне реальны, о чем свидетельствует обвинение евреев в распространении знаменитой эпидемии черной чумы, опустошившей земли северной Франции в середине XIV в., а также факт их избиения, который он объясняет проявлением ужаса и страха людей перед смертельной болезнью - страха, подкрепленного слухами об отравлении источников. Этих доводов Жирару достаточно, чтобы соотнести трагическую историю евреев с охотой на избранных жертв - «козлов отпущения», которая, по сути дела, и случилась в период эпидемии.

Следует подчеркнуть, что Жирар прибегает к понятию «козел отпущения» как к метафоре с глубоко религиозным, библейским смыслом, имеющим отношение к истории Иова в Ветхом Завете. Прежде чем более подробно рассмотреть этот ветхозаветный аспект понимания жертвы, всепрощения и бесконечной любви к Богу как способу преодоления гонений, вернемся к последовательности изложения текста книги Жирара.

Итак, для того, чтобы придать определенный смысл понятию «козел отпущения» в связи с действиями, представленными в поэме Гийома де Машо, Жирар ссылается на Лафонтена и его басню «Животные, заболевшие чумой», где баснописец говорит о необ- 
ходимости избавиться от напастей (кары небесной) посредством определения виновника, а назвав его, поступить с ним соответствующим образом - придать «божеству», то есть сделать жертвой. У Лафонтена осел как наименее кровожадное животное, и поэтому самое слабое и беззащитное, избирается жертвой. Но «придать божеству» в контексте рассуждений Жирара как раз и означает сделать «козлом отпущения» и придать гонениям.

Рассуждая по аналогии с Лафонтеном, Жирар не ограничивается только тем, что считает необходимым типизировать образ жертвы, соглашаясь с описанием, которое дает Лафонтен, назначая жертвой наиболее слабое и беззащитное существо. Допуская такой образ жертвы в принципе и используя его в качестве примера, Жирар идет в своих рассуждениях дальше. Он находит глубинные психологические корни и социально-культурные причины появления гонений и выстраивает целую теоретически нагруженную антропологическую конструкцию. Рассуждая как философ, Жирар связывает воедино феномен жертвы с гонением и объясняет различные типы гонений, известные истории, фундаментальной социоприродной сущностью самого человека, которая может проявить себя в кризисные моменты жизни отдельного человека или сообщества людей. Именно в моменты, когда появляется острая необходимость защитить себя и своих близких, могут включаться дремавшие прежде предрассудки и обнажаться примитивные верования с характерным, восходящим к архаике отношением к выживанию, построенном по принципу соотношения «охотник - жертва». «Если действительно случилась эпидемия, - пишет Жирар, - то она могла разжечь дремлющие предрассудки. Страсть к гонениям охотно фокусируется на религиозных меньшинствах, особенно в период кризиса» [Жирар 2010, 19]. Таким образом, несчастья, захватившие многих людей, могут разжечь предрассудки и связанную с ними «страсть к гонениям», основанную не только на разногласиях межнационального или религиозного характера, но опирающуюся на одно только воображение «гонителей», которые измышляют и преувеличивают «вину» своих жертв. Это заметно на другом примере гонений в истории человечества - печально изве- стной «охоте на ведьм», распространившейся по Европе в XVI в. Здесь выбор жертвы, осуждение и казнь построены исключительно на воображении самих гонителей с их примитивным, поощрявшим агрессивные действия, искаженным истолкованием смысла христианского вероучения. Надо заметить, что подобного рода негативные моменты истории случаются не только в периоды кризиса, но происходят вследствие утраты представлений об общечеловеческих ценностях, которые как раз и составляют организующий стержень культуры - культуры взаимоотношения людей, например, внутри многонационального государства, наряду с признанием ценности культуры каждого отдельного народа (страны, государства).

Для нас интересно не только то, как Жирар характеризует гонителей и их жертв, рассматривая и определяя их роль с позиции стороннего наблюдателя, исторически далеко отстоящего от рассматриваемых событий, но и то, по каким основаниям он определяет достоверность этих событий, придает им смысл. Рассуждая, по сути дела, как герменевтик, Жирар видит в тексте два важных аспекта в качестве основания для суждений о его достоверности: исторический контекст, связанный с определенным местом и временем описываемых действий, и социально-психологический контекст, «внутри которого факт резни приобретает почти непреложную достоверность» [Жирар 2010, 21].

Таким образом, концепция Рене Жирара основывается на двоякой герменевтической методологии: поиск главного смысла он ведет в направлении отвержения некоторых смыслов, признаваемых негативными и осуждаемыми, при одновременной переинтерпретации и переосмыслении других смыслов (через понятия 〈жертва», «вина», «гонение»), сулящих прорыв к новым измерениям истолкования рассматриваемого эпизода и самоценных для установления и утверждения исторической правды, связанной с обвинительными гонениями.

Центр тяжести смыслового поля истолковываемого текста-ситуации всегда будет обнаруживаться либо как негативный (и это сделать довольно легко в парадигме «козла отпущения»), либо как позитивный концепту- 
альный философский смысл, оппонирующий негативным тенденциям поиска «врага». Негативный смысл истолкования ситуации, связанной с образом «жертвы-врага», не обязательно разрушителен для целостного представления литературного произведения как имеющего историческую составляющую. В конечном итоге, в представленной панораме смыслов даже негативный смысл оказывается конструктивным, и он получен в результате эволюции первоначальных смыслов в процессе истолкования. В целом, правильность понимания может быть достигнута и на пути отрицания негативных смыслов самим интерпретатором (например, из-за внутреннего неприятия рассматриваемой ситуации), а не только лишь как точка зрения, подкрепленная позитивными моральными качествами, скрытыми в рассматриваемых смыслах.

\section{Типология гонительских стереотипов}

Жирар находит еще одно важное направление исследования человека для построения целостной антропологической концепции - речь идет об интерпретации скрытого смысла некоторых социально значимых действий людей, в частности, действий негативного или разрушительного характера, наблюдаемых с наибольшей очевидностью в переломные и так называемые ключевые моменты истории (смена династии, революция, смена власти в государстве, политический переворот, массовые беспорядки, террор и т. п.). В такие периоды истории как раз и случаются отдельные акты насилия, а также коллективные гонения, или «гонения с коллективной поддержкой», как называет их Жиpap. Под «коллективными гонениями» он понимает различные акты насилия, совершаемые толпой, воодушевляемой и подстрекаемой общественным мнением. Примерами коллективных гонений (актов насилия) являются избиения евреев в период черной чумы и «охота на ведьм» в эпоху средневековья.

Жирар настаивает на том, что все известные человечеству формы коллективного насилия и гонений имеют общие причины, независимо от того, где и когда это случается. Для определения смысла этих причин, он вводит новое теоретическое понятие - «стерео- типы кризиса» и связывает сам факт разрушительных действий толпы непосредственно с социальным кризисом, когда разрушаются социальные отношения, происходит распад социальных институтов, теряют свое значение иерархические связи и функциональные различия в обществе и наступает «затмение культуры» - именно тогда как раз и происходят коллективные гонения. Рассуждая о них с контексте истории и культуры, выявляя исторически сложившиеся типы коллективных гонений, рассматривая их особенности и внутреннюю связь, Жирар выстраивает типологию гонений, основываясь на выдвигаемых им «стереотипах обвинений» и ответственности жертв - мнимой или реальной. Первый гонительный стереотип он обнаруживает уже в тексте Гийома де Машо. Именно этот автор, согласно Жирару, «усматривает в эгоистической сосредоточенности индивида на самом себе и в проистекающей из нее динамике взаимных репрессий, то есть в парадоксально взаимных последствиях этого эгоизма, одну из причин чумы» [Жирар 2010, 31]. Тот же текст дает нам один из примеров так называемого обвинительного стереотипа - это обвинение евреев в отравлении рек и источников питьевой воды. «Типичность» подобного обвинения (при всей его абсурдности) заключается в том, что тот, кто наносит вред другим, остается незамеченным. В случае текста де Машо речь идет об использовании никому неизвестного яда как возможности нанести вред всем и остаться незамеченным.

Осуществляя видимость правосудия и истребляя «виновных», гонители называют жертву, исходя из тех преступлений, которые ей приписываются и на которые они реагируют, преследуя и карая виновных. В глазах гонителей любого толка (при любом типе гонений) их «жертвы» наделяются схожими чертами, по которым их определяют сами гонители, назначая ответственными за преступления перед людьми и обществом - реальные или мнимые. Смысл пагубного могущества коллективных гонителей состоит в предположении, что, покарав жертву и устранив «виновных», гонители смогут вернуть утерянный в результате кризиса социальный порядок в обществе или даже построят новый порядок. Так скрытый смысл гонений на религиозной 
основе (второй тип коллективных гонений в типологии Жирара), состоит в том, что по замыслу фанатичных ревнителей христианской веры, избавление от жертв должно привести к религиозному единению общества, «освеженного перенесенными испытаниями» [Жирар $2010,76]$. Но как при этом чувствую себя сами гонители? Что примиряет их с жертвой и возможны ли нормальные человеческие взаимоотношения в такие кризисные моменты и в дальнейшем? «Испытывающие ужас пред жертвой своих же рук, - подчеркивает Жиpap, - сами себя они воспринимают как целиком пассивных, безынициативных, целиком подвластных этому козлу отпущения даже в тот самый момент, когда они на него бросаются. Они считают, что всякая инициатива исходит от него. В их поле зрения есть место лишь для одной причины, и она торжествует абсолютно, она поглощает всякую иную причину, и эта причина - козел отпущения» [Жиpap 2010, 77].

Выстраивая типологию гонений по основаниям рационально-философским, исторически-реальным и религиозным, Жирар усматривает аналогию стереотипов гонения даже в мифологии. Например, в истории царя Эдипа, в мифе о рождении Зевса и коллективном спасении его куретами от гнева Кроноса, подчеркивая тем самым идею преемственной взаимосвязи гонительских практик, представленных в нарративах греческих мифов. Эти практики имеют фундаментальную антропологическую основу, которую способно раскрыть мифологическое мышление с его обращенностью к характеру поступков и действий богов, рассматриваемых в качестве образца или символизирующих то, что может происходить в человеческом обществе (и наоборот). Однако постепенно вся последующая философская мысль стремится преодолеть примитивную сакральность негативных действий мифологических богов, очистить смысл их пагубных поступков и преступлений от вины, сохранив за богами только положительный аспект их поступков и действий. «Изучение мифов наводит на мысль, что очень сильная тенденция минимизировать, а затем и ликвидировать преступления богов «поработала» над мифологиями, в особенности над греческой, задолго то того, как Платон и философы дали ей концептуальное выражение» [Жирар $2010,132]$. Олимпийские боги - это не жертвы, а эстетически приукрашенные художественные образы. Смысл поступков богов со временем идеализируется, и он не адаптирован под гонения, но трактуется исключительно как шалость, проказа, игра, в худшем случае как ничтожная ошибка или оплошность. «Для того чтобы желание извинить бога не приводило сразу же к полному устранению его вины (а именно этого на позднейшем этапе открыто требует Платон), какая-то сила должна продолжительно работать на поддержание предельного уважения к традиционному тексту, и этой силой может быть лишь длительный эффект козла отпущения, логика, присущая примитивной религии на ее ритуальной и жертвенной стадии» [Жирар 2010, 134]. Этим высказыванием Жирар подводит нас к необходимости обратиться к выяснению первоначального смысла самого понятия «козел отпущения» в его прямом и переносном значении.

Исторически первоначальный, буквальный смысл словосочетания «козел отпущения» восходит к ритуалу жертвоприношения древних евреев. «Козел отпущения» - так называют одного из двух козлов, приданных в жертву за грехи всего израильского общества. Первосвященник, возложив обе руки на животное, исповедовал над ним все грехи Израиля и этим действием как бы переносил все бремя ответственности народа непосредственно на него. Затем он низвергался со скалы в пропасть Цох и разбивался. Глубинный смысл ритуала жертвоприношения состоит в том, что он предполагает освобождение людей от подлинных несчастий, избавление от бед путем заместительной жертвы, взявшей на себя грехи других. При этом сам акт жертвоприношения должен был создавать зримое впечатление воздействия на подлинные причины бедствий народа и внушать надежду на скорое от них избавление. В последующие века такого рода практика приобрела уже вполне осознаваемый сакральный смысл воздействия на людей и предполагала исцеление общества через убийство избранной жертвы. Поэтому «козел отпущения〉 нужен, и он служит задаче трансформации разрушительного насилия в созидательное действие, часто сакральное. 
Другой, более сложный, символический смысл понятия «козел отпущения» восходит к тексту Книги Иова в Ветхом Завете. Книга Иова - один из древнейших образцов нравоучительной литературы Ближнего Востока. Согласно Оригену, она написана раньше Пятикнижия, и хотя точное время появления книги доподлинно неизвестно, по некоторым сведениям, содержащимся в тексте, толкователями-богословами высказывается предположение, что уже одно только символическое имя Иов (то есть «враждующий» или «обращенный») указывает на исторического Иова и на то, что он жил в патриархальный период (возможно, до Моисея), «так как он совмещал функции главы семьи, священника и судьи» [Иов 2013, 187]. Текст книги составлен из повествовательных и поэтических глав, в которых представлены дискуссия Иова с друзьями и ответ Бога Иову.

Иов - обладатель несметных стад и многочисленных слуг, отец семи сыновей и трех дочерей. Замечу, что число его детей (10) не случайно для Библии: 7 символизирует полноту, а 3 - начало всего. Свалившиеся на него бедствия начинаются с потери всего имущества, а затем и детей. Но и тогда Иов не ропщет, но поклоняется Господу со словами: Господь дал, Господь и взял; да будет имя Господне благословенно! Хотя в тексте Книги Иова мы не встретим словосочетание «козел отпущения», тем не менее, мы соотносим все, что случается с Иовом именно с таким пониманием судьбы невинного, но отверженного человека, притягивающего к себе всеобщую ненависть и агрессию. Иов - первый из всех отверженных, от которых отвернулся Бог; Иов - «жертва всех жертв». Почему с ним это произошло? Почему он стал отверженным в своей общине? Библия не дает прямого ответа. Но его пытаются найти толкователи-богословы на протяжении многих веков, а также современные интерпретаторы и исследователи. Как это могло случиться с Иовом? Еще вчера его благочестие было образцовым, его славили и превозносили соплеменники, а сегодня все хулят его и презирают. Следовательно, полагает Иов, изменился не он сам, а окружавшие его люди. Друзья Иова пытаются найти причины его бед и несчастий в тайных грехах или в преступлениях, которые со- вершили его близкие, но о которых он и не подозревает - и здесь аргументы «друзей» Иова направлены на то, чтобы Иов смирился, согласился с мыслью о том, что уже в самом возвышении человека есть что-то, что неизбежно готовит его падение.

Такая ситуация, говорит Библия, типична - это «путь древних, которым шли люди беззаконные». Более того, «беззаконие» людей считается доказанным уже только тем, что от них отвернулась община, а коллективному мнению (мнению толпы) отдается предпочтение на том основании, что единодушие «всех» уже только этим выражает непогрешимость божественной воли. В истории Иова скрытый смысл действий «всех против одного» состоит в том, чтобы заставить Иова согласиться с мнением толпы (взять на себя роль «козла отпущения», согласиться стать «жертвой»). В этом как раз и выражается сущность коллективного насилия. Но для того, чтобы коллективное насилие воспринималось группой людей как действие сакральное, невиновность жертвы должна быть сокрыта от толпы, а жертва должна признать свою виновность. Если же этого не происходит и единодушия толпы и жертвы не наступает, то и смысл гонения, в конечном счете, исчезает.

В целом, история Иова заканчивается благополучно: ему, как Праведнику, возвращается вдвое больше того, что он имел, включая рождение 10 детей. Хотя Иов не понимает, в чем его вина и упорно отрицает все обвинения людей, он не ропщет на Бога, но, раскаявшись в своем незнании перед ним, просит простить и за себя, и за других людей. «За других - потому что он всегда заботился об окружающих и помогал им. И когда Иов осудил себя, тогда Господь оправдал его и назвал Своим слугой» [Иов 2013, 294].

$$
* * *
$$

«Козел отпущения» становится для Жирара вертикалью, вокруг которой выстраивается структура и система смыслов интерпретации, принципом, позволяющим организовать и оценить все смысловые ситуации, возникающие в истории культуры. Это своеобразная волшебная призма, взгляд сквозь которую преображает понимание, придавая ему чет- 
кость и добавляя новые измерения, далеко не очевидные при поверхностном анализе текста или обычных ситуаций и смыслов. Как только эта вертикаль выстроена, как только объект подобного осмысления обнаружен и зафиксирован, весь ландшафт понимания перестает быть тривиальным, выходя за рамки обыденности, порой приобретая трансцендентальные аспекты. Не случайно Жирар рассуждает о мифологической, религиозной и рациональной основе в выстраиваемой им антропологической концепции - понимании человека и его природы сквозь призму жертв и гонений. Вся смысловая глубина возникает там, где раньше не было и намека на необходимость понимания глубинных смыслов и их концептуального истолкования. Именно в этой традиции работает мысль и аргументация Жирара. В центре его внимания человеческие отношения. Но не те, что сопровождают нашу повседневность, а те, которые происходят между представителями разных культур, смысл которых становится понятен благодаря истолкованию, обращенному к текстам, в том числе к текстам конкретных исторических эпох и культур.

Новаторский характер исследования Жирара состоит в том, что он выстраивает собственную концепцию видения человека в исторической парадигме и при этом состыковывает образы культур, используя «особые понятия и теоретические конструкты, которые выходят за рамки обыденного смысла» [Степин 2015, 209]. Он придает таким понятиям как «жертва», «гонения», «вина», «стереотипы обвинений», «козел отпущения» философский смысл. Причем этически воспринимаемый конкретный смысл этих понятий, связанный с определенными действиями и поступками людей, их оценкой Жирар как раз и делает главным и конституирующим в своей антропологической концепции. Он придает образам культуры герменевтически оправданную определенность даже в тех случаях, когда текст повествует о характере действий, направленных на жертву. Важно, что Жирар при этом выделяет фундаментальные основания человеческих действий негативного характера, связанные с уничтожением, разрушением и т. д., рассматривая их с самых разных позиций: с точки зрения гонительских ис- кажений или стереотипных обвинений. Ученый приходит к пониманию необходимости типизировать эти стереотипы гонений, рассматривая их с мифологической позиции, сугубо религиозной или реалистической, которую наиболее просто понять современному читателю и исследователю. Он приходит к выводу, что в каждый период истории, в каждом конкретном обществе, в каждой конкретной культурной среде есть свои жертвы и есть свои гонители, иначе говоря, свои формы дискриминации. Их критерии определяются по культурным или религиозным основаниям. «В Индии гонениям подвергаются прежде всего мусульмане, а в Пакистане - индуисты. Стало быть, при всем очевидном различии существуют универсальные признаки жертвенного отбора - именно они составляют наш третий стереотип» [Жирар 2010, 37].

Иногда невозможно провести границу между дискриминацией и коллективным гонением. Хотя Жирар не стремится описать границы гонений с абсолютной точностью, он указывает, что существуют политические, моральные и даже медицинские причины, по которым некоторые формы социальных ограничений представляются вполне разумными, но в чем-то похожими на формы гонений, о которых шла речь. «Так, например, обстоит дело с помещением в карантин во время эпидемий всякого, кто может оказаться заразным. В Средние века врачи враждебно относились к идее, будто чума может распространяться посредством физического контакта с больными. Дело в том, что врачи, в целом, принадлежали к просвещенным кругам, а любая теория заражения слишком уж напоминала гонительские предрассудки и потому казалась им подозрительной» [Жирар 2010, 39]. К счастью, как пишет сам Жирар, ученые более поздних времен уже не придерживаются гонительской ментальности, и подобная «жертвенная» аргументация не способна повлиять на их научные выводы и связанные с ними рекомендации. Вместе с тем в отношении социально-политических процессов подобная опасность все же существует, делая по-прежнему актуальным герменевтический анализ человеческой ситуации в периоды кризиса с учетом философских оснований истолкования и понимания невзгод или катастроф Рене Жираром. 


\section{СПИСОК ЛИТЕРАТУРЫ}

Жирар 2000 - Жирар Р. Насилие и священное / пер. с фр. Г. Дашевского. М.: Новое литературное обозрение, 2000.

Жирар 2010 - Жирар Р. Козел отпущения / пер. с фр. Г. Дашевского. СПб.: Изд-во Ивана Лимбаха, 2010.

Жирар 2012 - Жирар Р. Критика из подполья / пер. с фр. Н. Мовниной. М.: Новое литературное обозрение, 2012.

Жирар 2015 - Жирар Р. Я вижу Сатану, падающего как молния. М.: Изд-во ББИ, 2015.

Жирар 2016 - Жирар Р. Вещи, сокрытые от создания мира. М.: Изд-во ББИ, 2016.

Иов 2013 - Иов / Книга Иова. В русском синодальном переводе. Составление и комментарий В. Романенко, составление и предисловие иеромонаха Симеона (Томачинского). Киев: Богуславкнига, 2013.

Степин 2015 - Степин В.С. Философская антропология и философия культуры. М.: Академический проект : Альма Матер, 2015.

Шульга 2008 - Шульга Е.Н. Понимание и интерпретация. М.: Наука, 2008.

Girard 1985 - Girard R. La Route antique des hommes pervers. Paris: Grasset, 1985.

Goodhart et al. (eds.) 2009 - Goodhart S., Jørgensen J., Ryba T., Williams J.G. (eds.). For René Girard: essays in friendship and in truth. East Lansing: Michigan State University Press, 2009.

McKenna 1992 - McKenna A.J. Violence and Difference: Girard, Derrida, and Deconstruction. Chicago: University of Illinois Press, 1992.

Meszaros, Zachhuber 2013 - Meszaros J., Zachhuber J. (eds.). Sacrifice and Modern Thought. New York: Oxford University Press. 2013.

Palaver 2013 - Palaver W. René Girard's Mimetic Theory. E. Lansing, MI: Michigan State University Press, 2013.

Reineke 2014 - Reineke M.J. Intimate Domain: Desire, Trauma, and Mimetic Theory. East Lansing: Michigan State University Press, 2014.

Ryba, Redekop 2013 - Ryba T., Redekop V.N. (eds.). René Girard and Creative Mimesis. Lanham, Maryland: Lexington Books, 2013.

Schwager 2000 - Schwager R.S. Must There Be Scapegoats? Violence and Redemption in the Bible. New York: Crossroad, 2000.

Smith, Wallace 1994 - Smith T.H., Wallace M.I. Curing Violence: Essays on René Girard. Sonoma, CA: Polebridge Press. 1994.
Swartley 2000 - Swartley W.M. (ed.) Violence Renounced: René Girard, Biblical Studies, and Peacemaking. Telford, PA: Cascadia Publishing House, 2000.

\section{REFERENCES}

Girard R., 1963. Dostoïevski, du double à l'unité. Paris, Plon.

Girard R., 2010. The Scapegoat. SPb, Ivan Limbakh Publ.

Girard R., 1978. Des choses cachées depuis la fondation du monde. Paris, Grasset.

Girard R., 1999. Je vois Satan tomber comme l'éclair. Paris, Grasset.

Girard R., 1972. La Violence et le Sacré. Paris, Grasset. Job / The Book of Job, 2013. Kiev, Boguslavkniga Publ.

Stepin V.S., 2015. Philosophical Anthropology and Philosophy of Culture. Moscow, Akademicheskij proekt, Alma Mater Publ.

Shulga E.N., 2008. Understanding and interpretation. Moscow, Nauka Publ.

Girard R., 1985. La Route antique des hommes pervers. Paris, Grasset.

Goodhart S. et al. (eds.), 2009. For René Girard: essays in friendship and in truth. East Lansing: Michigan State University Press.

McKenna A.J., 1992. Violence and Difference: Girard, Derrida, and Deconstruction. Chicago: University of Illinois Press.

Meszaros J., Zachhuber J. (eds.), 2013. Sacrifice and Modern Thought. New York, Oxford University Press.

Palaver W., 2013. René Girard's Mimetic Theory. E. Lansing, MI, Michigan State University Press.

Reineke M.J., 2014. Intimate Domain: Desire, Trauma, and Mimetic Theory. East Lansing, Michigan State University Press.

Ryba T., Redekop V.N. (eds.), 2013. René Girard and Creative Mimesis. Lanham, Maryland, Lexington Books.

Schwager R.S.J., 2000. Must There Be Scapegoats? Violence and Redemption in the Bible. New York, Crossroad.

Smith T.H., Wallace M.I., 1994. Curing Violence: Essays on René Girard. Sonoma, CA, Polebridge Press.

Swartley W.M. (ed.), 2000. Violence Renounced: René Girard, Biblical Studies, and Peacemaking. Telford, PA, Cascadia Publishing House. 


\section{Information About the Author}

Elena N. Shulga, Doctor of Sciences (Philosophy), Leading Researcher, Institute of Philosophy, Russian Academy of Sciences, Goncharnaya St, 12, 119019 Moscow, Russian Federation, elena.shulga501@gmail.com, https://orcid.org/0000-0002-4570-9377

\section{Информация об авторе}

Елена Николаевна Шульга, доктор философских наук, ведущий научный сотрудник, Институт философии РАН, ул. Гончарная, 12, 119019 г. Москва, Российская Федерация, elena.shulga501@gmail.com, https://orcid.org/0000-0002-4570-9377 